\title{
Spray Pyrolysis Deposition of Single and Mixed Oxide Thin Films
}

\author{
Olusegun J. Ilegbusi ${ }^{*}$, S. M. Navid Khatami1 ${ }^{1}$ Leonid I. Trakhtenberge,3 \\ ${ }^{1}$ Department of Mechanical and Aerospace Engineering, University of Central Florida, Orlando, FL, USA \\ ${ }^{2}$ Semenov Institute of Chemical Physics, Russian Academy of Sciences, Moscow, Russia \\ ${ }^{3}$ Moscow Institute of Physics and Technology (State University), Dolgoprudny, Moscow Region, Russia \\ Email: ^ilegbusi@ucf.edu
}

How to cite this paper: Ilegbusi, O.J., Khatami, S.M.N. and Trakhtenberg, L.I. (2017) Spray Pyrolysis Deposition of Single and Mixed Oxide Thin Films. Materials Sciences and Applications, 8, 153-169.

https://doi.org/10.4236/msa.2017.82010

Received: May 27, 2016

Accepted: February 3, 2017

Published: February 6, 2017

Copyright $\odot 2017$ by authors and Scientific Research Publishing Inc. This work is licensed under the Creative Commons Attribution International License (CC BY 4.0).

http://creativecommons.org/licenses/by/4.0/

\begin{abstract}
The influence of processing parameters is investigated on the structural characteristics of single and mixed oxides produced by spray pyrolysis technique. The films were synthesized by spraying precursor solutions through a nozzle onto a heated alumina substrate. The precursor consisted separately of aqueous solutions of tin chloride for $\mathrm{SnO}_{2}$ and zinc chloride for $\mathrm{ZnO}$ for single oxide cases, and aqueous solutions of tin chloride and indium nitrate for $\mathrm{SnO}_{2}+\mathrm{In}_{2} \mathrm{O}_{3}$ and zinc chloride and indium nitrate solutions for $\mathrm{ZnO}+\operatorname{In}_{2} \mathrm{O}_{3}$ for mixed oxide cases. The substrate temperature was varied accordingly for each single and mixed case. The films produced were characterized by X-ray Photoelectron Spectroscopy and Scanning Electron Microscopy. The results indicate that a non-homogenous film is formed at low temperature for both single oxides considered. The temperature has significant effect on the composition of the synthesized films of both single oxides below $450^{\circ} \mathrm{C}$. The results for mixed oxides show that the best homogeneous films are obtained for $80 \mathrm{wt} \% \mathrm{ZnO}+20 \mathrm{wt} \% \mathrm{In}_{2} \mathrm{O}_{3}$, and $80 \mathrm{wt} \% \mathrm{SnO}_{2}+20 \mathrm{wt} \% \mathrm{In}_{2} \mathrm{O}_{3}$.
\end{abstract}

\section{Keywords}

Zinc Oxide Film, Tin Oxide Film, Mixed Metal Oxides, Nano-Composite Sensors, Spray Pyrolysis

\section{Introduction}

Metal oxide semiconductor films are widely used for gas sensors. The properties of such sensors including sensitivity, selectivity and response time depend critically on the film microstructure [1]. The structure in turn is largely determined by the synthesis condition [2]. Such films are usually synthesized by a variety of techniques including Spray Pyrolysis Technique-SPT [3], sol-gel technique [4], 
and chemical vapor deposition (CVD) [5]. The objective of this study is to investigate the effect of synthesis conditions (specifically, substrate temperature and precursor concentration) on the structure of $\mathrm{ZnO}, \mathrm{SnO}_{2}, \mathrm{ZnO}+\mathrm{In}_{2} \mathrm{O}_{3}$ and $\mathrm{SnO}_{2}$ $+\mathrm{In}_{2} \mathrm{O}_{3}$ thin films produced by SPT. This technique has been employed in this study due to its inherent advantages, including the ease of control, low cost, and simplicity [6] [7].

Several studies have considered the deposition of $\mathrm{ZnO}$ films. A study on the effect of post annealing on the properties of $\mathrm{ZnO}$ films shows that annealing enhances the quality of film by removing structural defects through agglomeration of small particles. The results indicated that post-thermal annealing could enhance the structural quality in general [8] [9]. A similar approach has been used to synthesize $\mathrm{ZnS}$ and $\mathrm{ZnO}$ thin films, and study the growth mechanism and film characteristics (such as structure and crystalline properties) as a function of temperature, solution composition and concentration [10]. The effect of temperature on $\mathrm{ZnO}$ film structure has also been investigated, indicating that such films could be crystallized better at substrate temperatures above $400^{\circ} \mathrm{C}$ [11].

The influence of deposition parameters on $\mathrm{SnO}_{2}$ thin film characteristics has demonstrated that SPT could be used to produce nano-scale films for gas sensing applications [12]. The electrical and structural properties of $\mathrm{SnO}_{2}$ films deposited by SPT also show improvement of crystal growth at high temperatures (above $450^{\circ} \mathrm{C}$ ) [13].

Mixing of metal oxides in a sensor film has recently been explored to improve sensor performance and thermal stability. The mixed oxides have the potential to benefit from the best sensing properties of their pure components. The electronic structures of the oxides are modified, resulting in change to both the bulk and surface properties [14].

Some research studies have investigated the properties of indium-doped $\mathrm{ZnO}$ nanofiber thin films by SPT, using temperatures between $350^{\circ} \mathrm{C}$ and $500^{\circ} \mathrm{C}$ for film deposition and $500^{\circ} \mathrm{C}$ for annealing. The results indicate a decrease in grain size with increasing temperature [15] [16].

Similar studies have investigated the effect of deposition parameters on the characteristics of indium-doped $\mathrm{SnO}_{2}$ films as well as $\mathrm{ZnO}$. The studies used low temperature $\left(380^{\circ} \mathrm{C}\right)$ for deposition of zinc-indium oxides and higher temperature $\left(450^{\circ} \mathrm{C}\right)$ for tin-indium oxides at ambient atmosphere [17].

Two primary synthesis parameters controlling the structure of films produced by SPT are the substrate temperature and the concentration of precursors in solution. Although several studies have considered the effect of substrate temperature and solution concentration on the structure of metal oxide films [18], there is a lack of systematic investigation of the effect of temperature on different oxides synthesized by SPT under similar controlled conditions. This issue is addressed in the present study by maintaining constant values of some process parameters (e.g. spray nozzle diameter, spray velocity, and distance between spray nozzle and substrate), while varying the temperature. In addition, the effect of precursor concentration is similarly investigated. 


\section{Experiments Performed}

\subsection{Deposition Mechanism}

The SPT setup utilized is illustrated in Figure 1 [19]. A precursor solution which contains constituent reactant compounds is atomized in a nozzle to tiny droplets which are then sprayed onto a preheated substrate. The surface of the substrate must be sufficiently hot to initiate chemical reaction between the precursors in the droplet solution. Specifically, the droplet must still contain enough reactants in solution after reaching the substrate [20]. A film of stable compounds subsequently forms that adheres to the substrate due to chemical reaction and thermal decomposition of the solution.

\subsection{Experimental Procedure}

The primary focus of the study was the processing of mixed oxide nanocomposite films $\left(\mathrm{ZnO}+\mathrm{In}_{2} \mathrm{O}_{3}\right.$ and $\left.\mathrm{SnO}_{2}+\mathrm{In}_{2} \mathrm{O}_{3}\right)$. However, the single oxides $\left(\mathrm{ZnCl}_{2}\right.$ and $\mathrm{SnCl}_{4}$ ) were first investigated as benchmarks for the mixed oxides.

Zinc oxide was deposited using aqueous solution of zinc chloride $\left(\mathrm{ZnCl}_{2}\right)$ precursor while tin oxide utilized tin chloride $\left(\mathrm{SnCl}_{4}\right)$ precursor solution in water. The chemical reactions can be formulated thus [21]:

$$
\begin{gathered}
\mathrm{SnCl}_{4(1)}+2 \mathrm{H}_{2} \mathrm{O} \rightarrow \mathrm{SnO}_{2}+4 \mathrm{HCl}_{(\mathrm{g})} \\
\mathrm{ZnCl}_{2(1)}+\mathrm{H}_{2} \mathrm{O} \rightarrow \mathrm{ZnO}+2 \mathrm{HCl}_{(\mathrm{g})}
\end{gathered}
$$

It should be noted that the reaction of tin chloride solution is a heterogeneous reaction that occurs in the vapor phase [12].

In order to deposit mixed oxides, tin chloride and indium nitrate were dissolved together in water to synthesize $\mathrm{SnO}_{2}+\mathrm{In}_{2} \mathrm{O}_{3}$. Zinc chloride and indium nitrate were used for deposition of $\mathrm{ZnO}+\operatorname{In}_{2} \mathrm{O}_{3}$ for different composition ratios. Each precursor was fed into a $2 \mathrm{~mm}$-diameter duct at a flow rate of $1 \mathrm{ml} / \mathrm{min}$ [22]. The solution was injected through a $1 \mathrm{~mm}$-diameter round spray nozzle and then atomized at 1 bar air pressure. The solution in the nozzle was then sprayed onto a heated aluminum oxide $\left(\mathrm{Al}_{2} \mathrm{O}_{3}\right)$ coated substrate. The distance between the spray nozzle and the hot substrate was kept constant at $10 \mathrm{~cm}$ for

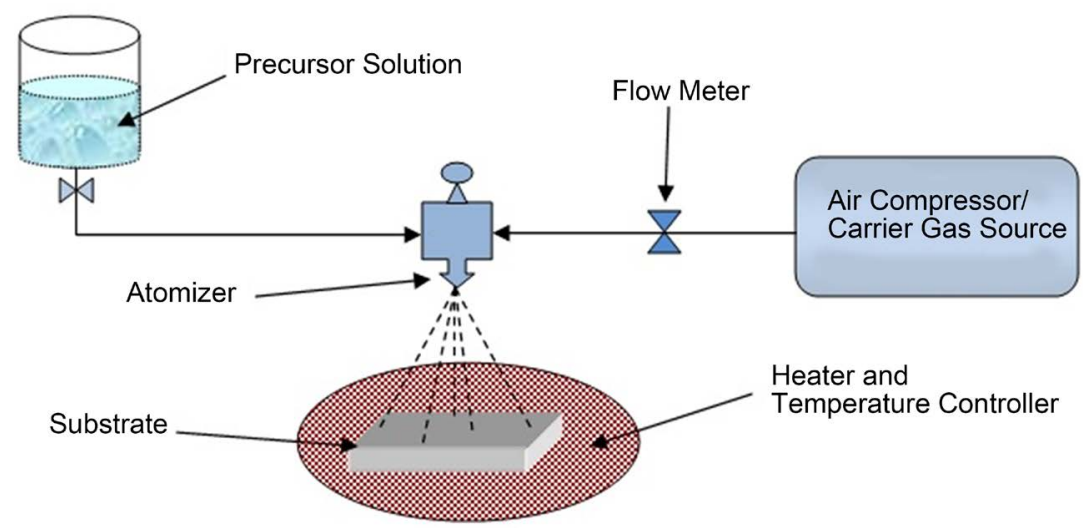

Figure 1. Schematic sketch of chemical spray pyrolysis process. 
the experiments. This distance was chosen based on the results of previous studies [19] [23]. The thin film was finally annealed for 30 minutes after deposition to the desired structures at $450^{\circ} \mathrm{C}$ [8] [24] [25]. The annealing process promotes adhesion of the film to the substrate. These conditions were kept constant for all other sets of experiments performed.

\subsection{Control Parameters}

The substrate Temperature $\left(T_{s}\right)$ and solution concentration $(C)$ were used as the control parameters. In order to assess the results of mixed oxide deposition, the optimum case from single oxide deposition was also considered.

Two sets of experiments were designed for deposition of $\mathrm{ZnO}$. In the first set of experiments (Cases 1 and 2), the concentration was maintained constant ( $C=$ $0.1 \mathrm{~mol} / \mathrm{lit}$ ) while the temperature was varied from $400^{\circ} \mathrm{C}$ to $450^{\circ} \mathrm{C}$. In the second set (Cases 3 and 4), the concentration was increased from $C=0.2 \mathrm{~mol} / \mathrm{lit}$ for Case 3 to $0.3 \mathrm{~mol} / \mathrm{lit}$ for Case 4 while the temperature was constant at $400^{\circ} \mathrm{C}$ [26].

The same approach was used for deposition of $\mathrm{SnO}_{2}$. In the first set (Cases 5 to 8), the substrate temperature $\left(T_{s}\right)$ was varied from $350^{\circ} \mathrm{C}$ to $500^{\circ} \mathrm{C}$ at 50 degrees increments for different sets of experiments while the concentration was constant at $0.25 \mathrm{~mol} / \mathrm{lit}$. In the second set (Cases 9 and 10), the temperature was kept constant at $450^{\circ} \mathrm{C}$ while the concentration was varied from 0.1 to $0.5 \mathrm{~mol} / \mathrm{lit}$ [12] [27].

In order to deposit mixed oxide films, the precursor concentration ratio was changed for new sets of experiments. Indium nitrate was mixed with zinc chloride to produce $25 \mathrm{wt} \% \mathrm{ZnO}+75 \mathrm{wt} \%$ (Case 11) and $80 \mathrm{wt} \% \mathrm{ZnO}+20 \mathrm{wt} \%$ $\mathrm{In}_{2} \mathrm{O}_{3}$ (Case 12). For these cases, temperature and solution concentration were kept constant at $400^{\circ} \mathrm{C}$ and $0.1 \mathrm{~mol} / \mathrm{lit}$, respectively. For deposition of $\mathrm{SnO}_{2}+$ $\mathrm{In}_{2} \mathrm{O}_{3}$, indium nitrate was added to produce $80 \mathrm{wt} \% \mathrm{SnO}_{2}+20 \mathrm{wt} \%$ (Case 13) and $95 \mathrm{wt} \% \mathrm{SnO}_{2}+5 \mathrm{wt} \% \mathrm{In}_{2} \mathrm{O}_{3}$ (Case 14).

\subsection{Material Characterization}

The deposited thin films were characterized by X-ray photoelectron spectroscopy (XPS) and Scanning electron microscopy (SEM). Surface morphology was studied using a Zeiss ULTRA-55 FEG SEM system which used Schottky field emission source with a resolution of $1 \mathrm{~nm} @ 15 \mathrm{KV}$ and $1.7 \mathrm{~nm} @ 1 \mathrm{KV}$ and STEM detector. Surface spectroscopy was performed by Physical Electronics 5400 ESCA system to detect elemental composition.

\section{Results}

Table 1 summarizes the various cases considered and the corresponding substrate temperature $\left(T_{s}\right)$, precursor concentration $(C)$ and the observed morphology for the various films produced. The results show that the resulting film structure is strongly dependent on the deposition temperature in each case. However the qualities of films were found to be enhanced by systematically 
Table 1. Film morphology of deposited films.

\begin{tabular}{|c|c|c|c|c|}
\hline Case & Film composition & $\begin{array}{c}\text { Temperature } \\
\left(T_{s}\right)\left[{ }^{\circ} \mathrm{C}\right]\end{array}$ & $\begin{array}{c}\text { Concentration } \\
\text { (C) }[\mathrm{mol} / \mathrm{lit}]\end{array}$ & Film morphology \\
\hline 1 & $\mathrm{ZnO}$ & 400 & 0.1 & Granular \\
\hline 2 & $\mathrm{ZnO}$ & 450 & 0.1 & Dense \\
\hline 3 & $\mathrm{ZnO}$ & 400 & 0.2 & Columnar \\
\hline 4 & $\mathrm{ZnO}$ & 400 & 0.3 & Columnar \\
\hline 5 & $\mathrm{SnO}_{2}$ & 350 & 0.25 & Dense \\
\hline 6 & $\mathrm{SnO}_{2}$ & 400 & 0.25 & Non-homogenous \\
\hline 7 & $\mathrm{SnO}_{2}$ & 450 & 0.25 & Porous \\
\hline 8 & $\mathrm{SnO}_{2}$ & 500 & 0.25 & Dense \\
\hline 9 & $\mathrm{SnO}_{2}$ & 450 & 0.1 & Dense \\
\hline 10 & $\mathrm{SnO}_{2}$ & 450 & 0.5 & Granular \\
\hline 11 & $25 \mathrm{wt} \% \mathrm{ZnO}+75 \mathrm{wt} \% \mathrm{In}_{2} \mathrm{O}_{3}$ & 0.1 & 400 & Columnar \\
\hline 12 & $80 w t \% \mathrm{ZnO}+20$ wt $\% \mathrm{In}_{2} \mathrm{O}_{3}$ & 0.1 & 400 & Columnar \\
\hline 13 & $80 w t \% \mathrm{SnO}_{2}+20 w t \% \mathrm{In}_{2} \mathrm{O}_{3}$ & 0.25 & 450 & Granular \\
\hline 14 & $95 \mathrm{wt} \% \mathrm{SnO}_{2}+5 \mathrm{wt} \% \mathrm{In}_{2} \mathrm{O}_{3}$ & 0.25 & 450 & Dense \\
\hline
\end{tabular}

increasing the precursor concentration. The effect of these two processing parameters is investigated in this section.

\subsection{Single Oxides}

\subsubsection{Effect of Substrate Temperature}

Figure 2 shows the SEM micrographs of $\mathrm{ZnO}$ films (Cases 1 to 4). Figure 2(a) and Figure 2(b) show the deposition of $\mathrm{ZnO}$ at low concentration $(C=0.1$ $\mathrm{mol} / \mathrm{lit})$ and different temperatures $\left(T_{s}=400^{\circ} \mathrm{C}\right.$ and $\left.T_{s}=450^{\circ} \mathrm{C}\right)$ while Figure 2 (c) and Figure 2(d) show the deposition at constant temperature $\left(T_{s}=400^{\circ} \mathrm{C}\right)$ and higher concentrations ( $C=0.2 \mathrm{~mol} /$ lit and $C=0.3 \mathrm{~mol} / \mathrm{lit}$ ), respectively.

Figure 2(a) (Case 1: $T_{s}=400^{\circ} \mathrm{C}$ and $C=0.1 \mathrm{~mol} / \mathrm{lit}$ ) shows that small spherical crystallites are formed that agglomerate at the surface in the shape of powder with an average size of $\sim 50 \mathrm{~nm}$ in the consensus of previous studies [28] [29] [30]. In Figure 2(b) (higher temperature of $T_{s}=450^{\circ} \mathrm{C}$ ), the film uniformity is enhanced due to the progression of chemical reaction at the higher temperature. The film is denser and the growth rate is highly limited by diffusion. The results are in good agreement with a previous study [31].

Temperature has similar effect on the deposition of $\mathrm{SnO}_{2}$ film (cases 5 to 10). Table 1 shows that a dense film is formed at the lowest temperature (Case 5, $350^{\circ} \mathrm{C}$ ). This result may be attributed to the limited evaporation of the droplets reaching the surface at low temperature. Some cracks are observed in the film due to thermal stress during the annealing process [32]. In addition, the precursor solution does not have sufficient time to form a continuous film on the $\mathrm{Al}_{2} \mathrm{O}_{3}$ substrate. As the temperature increases, a non-stoichiometric film with rough aspect ratio is formed (Table 1, Case 6). In this case, the nucleation process is faster due to the higher temperature [33] and a film with a non-homogenous structure is synthesized which is similar to the previous $\mathrm{ZnO}$ films deposited at 
low temperature (Figure 2, Case 1).

Figure 3 shows the SEM micrographs of some $\mathrm{SnO}_{2}$ films produced (Cases 7 to 10). Figure 3(a) and Figure 3(b) show the deposition of $\mathrm{SnO}_{2}$ at low concentration $(C=0.25 \mathrm{~mol} / \mathrm{lit})$ and different temperatures $\left(T_{s}=450^{\circ} \mathrm{C}\right.$ and $T_{s}=$ $500^{\circ} \mathrm{C}$ ) while Figure $3(\mathrm{c})$ and Figure $3(\mathrm{~d})$ show the deposition at constant

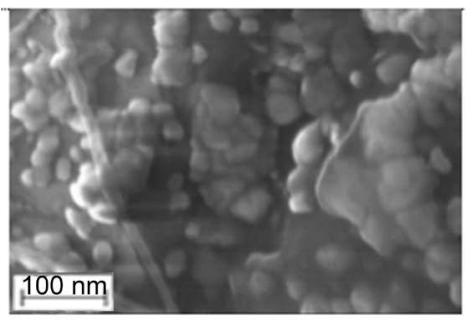

(a) Case 1

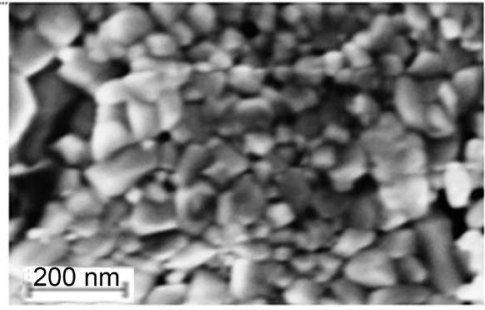

(c) Case 3

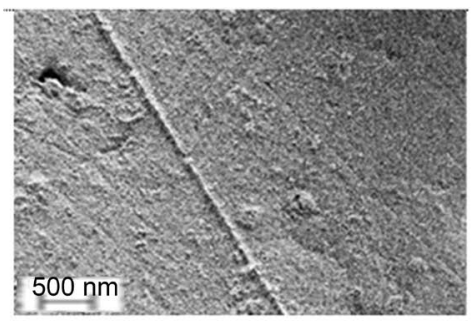

(b) Case 2

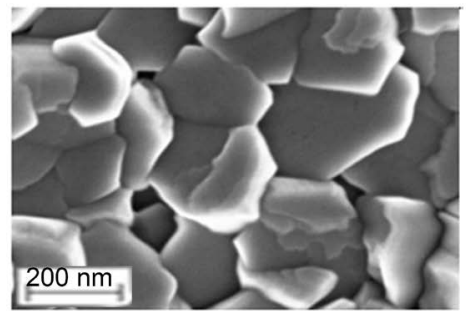

(d) Case 4

Figure 2. SEM micrographs of spray pyrolysis deposition of $\mathrm{ZnO}$ thin films on $\mathrm{Al}_{2} \mathrm{O}_{3}$ substrate: (a) $T_{s}=400^{\circ} \mathrm{C}$ and $C=0.1 \mathrm{~mol} / \mathrm{lit}$; (b) $T_{s}=450^{\circ} \mathrm{C}$ and $C$ $=0.1 \mathrm{~mol} / \mathrm{lit}$; (c) $T_{s}=400^{\circ} \mathrm{C}$ and $C=0.2 \mathrm{~mol} / \mathrm{lit}$; and (d) $T_{s}=400^{\circ} \mathrm{C}$ and $C=$ $0.3 \mathrm{~mol} / \mathrm{lit}$.

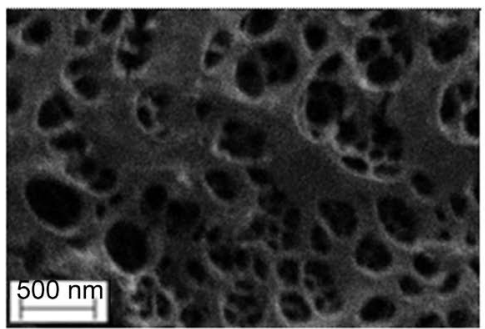

(a) Case 7

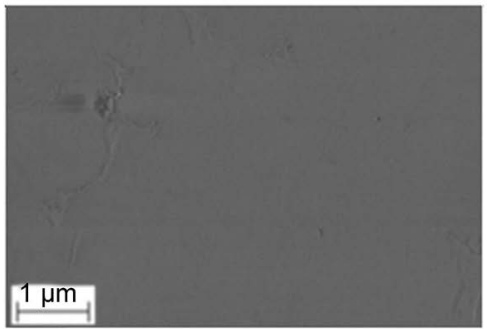

(c) Case 9

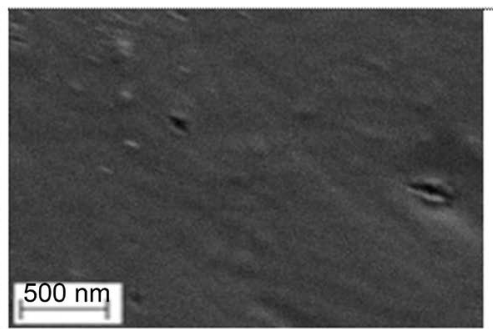

(b) Case 8

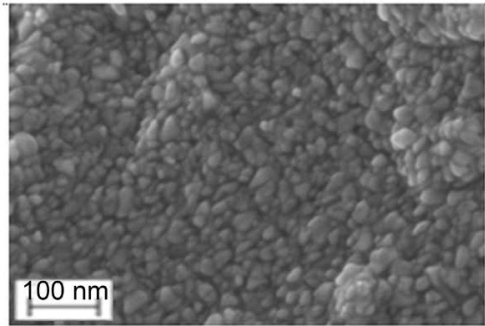

(d) Case 10

Figure 3. SEM micrographs of spray pyrolysis deposition of $\mathrm{SnO}_{2}$ thin films on $\mathrm{Al}_{2} \mathrm{O}_{3}$ substrate: (a) $T_{s}=450^{\circ} \mathrm{C}$ and $C=0.25 \mathrm{~mol} / \mathrm{lit}$; (b) $T_{s}=500^{\circ} \mathrm{C}$ and $C=0.25 \mathrm{~mol} / \mathrm{lit}$; (c) $T_{s}=450^{\circ} \mathrm{C}$ and $C=0.1 \mathrm{~mol} / \mathrm{lit}$ and (d) $T_{s}=450^{\circ} \mathrm{C}$ and $C=0.5 \mathrm{~mol} / \mathrm{lit}$. 
temperature $\left(T_{s}=450^{\circ} \mathrm{C}\right)$ and different concentrations $(C=0.1 \mathrm{~mol} / \mathrm{lit}$ and $C=$ $0.5 \mathrm{~mol} / \mathrm{lit})$.

Figure 3(a) $\left(T_{s}=450^{\circ} \mathrm{C}\right)$ and Figure $3(\mathrm{~b})\left(T_{s}=500^{\circ} \mathrm{C}\right)$ show thin films with continuous structure at both temperatures while the precursor solution is constant at $C=0.25 \mathrm{~mol} / \mathrm{lit}$. At $450^{\circ} \mathrm{C}$ (Figure 3(a)), the deposited film exhibits porous structure which prevents homogeneity. Such a characteristic porous microstructure has also been observed in a previous study [24]. The pore sizes are in the sub-micron range. The increase in porosity can be attributed to increased temperature and the film becomes denser without cracks at higher temperature [32], as observed in Figure 3(b). In this case, the pores shrink and the film surface subsequently becomes smooth.

The compositions of the deposited films are determined by X-ray photoelectron spectroscopy (XPS). Figure 4(a) shows the XPS of $\mathrm{ZnO}$ film grown at $400^{\circ} \mathrm{C}$ (Case 1). The corresponding result at $450^{\circ} \mathrm{C}$ (Case 2) is shown in Figure 4(b). $\mathrm{ZnO}$ deposition is clearly evident in both cases. However the atomic concentration of $\mathrm{Zn}$ increases from $0.9 \%$ at $400^{\circ} \mathrm{C}$ to $7.1 \%$ at $450^{\circ} \mathrm{C}$ due to the enhanced chemical reaction at the higher temperature. The peak of $\mathrm{Zn} 2 \mathrm{P}_{3}$ is associated with the $\mathrm{Zn}-\mathrm{O}$ bond [31].

Figure 5(a) and Figure 5(b) show the XPS results for $\mathrm{SnO}_{2}$ films deposited at $450^{\circ} \mathrm{C}$ (Case 7) and $500^{\circ} \mathrm{C}$ (Case 8). These results clearly confirm the formation and deposition of $\mathrm{SnO}_{2}$ at both temperatures, and exhibit the same atomic concentration of $\mathrm{Sn}$ at both temperatures. The result therefore shows that the temperature appears to have minimal effect on the atomic concentrations above $450^{\circ} \mathrm{C}$

\subsubsection{Effect of Solution Concentration}

The effect of concentration on deposition of $\mathrm{ZnO}$ are also presented in the previous Figure 2(c) (Case 3: $T_{s}=400^{\circ} \mathrm{C}$ and $C=0.2 \mathrm{~mol} / \mathrm{lit}$ ) and Figure 2(d) (Case 4: $T_{s}=400^{\circ} \mathrm{C}$ and $C=0.3 \mathrm{~mol} / \mathrm{lit}$ ). The results show that the grain size increases with increase in the amount of precursor dissolved in solution. The deposited grains tend to form crystalline shapes at higher concentrations (Figure $2(d))$. Figure 2(c) shows that at a lower concentration, the film is uniform with nanoparticle sizes of $\sim 100 \mathrm{~nm}$ with hexagonal flake-like morphology which is in the consensus of a previous study that utilized the same concentration of precursors [34]. When the concentration is increased, the density and size of particles are further increased. In Figure 2(d), the crystals are plate-like and the sides of the walls are grown packed as was also observed in a previous study [35]. A larger size of grains was similarly observed at the higher concentration [36].

The effect of concentration on the deposition of $\mathrm{SnO}_{2}$ can similarly be assessed by comparing Figure 3(c) (Case 9: $T_{s}=450^{\circ} \mathrm{C}$ and $C=0.1 \mathrm{~mol} / \mathrm{lit}$ ) and Figure 3(d) (Case 10: $T_{s}=450^{\circ} \mathrm{C}$ and $C=0.5 \mathrm{~mol} / \mathrm{lit}$ ). At low concentration, the grains form smooth, uniform thin film observed in Figure 3(c). A previous study has shown that at low concentrations, the film surface is smooth with no well-defined crystallites [37]. However by increasing the concentration, the particles begin to agglomerate and form clusters. These particles have sharpened 


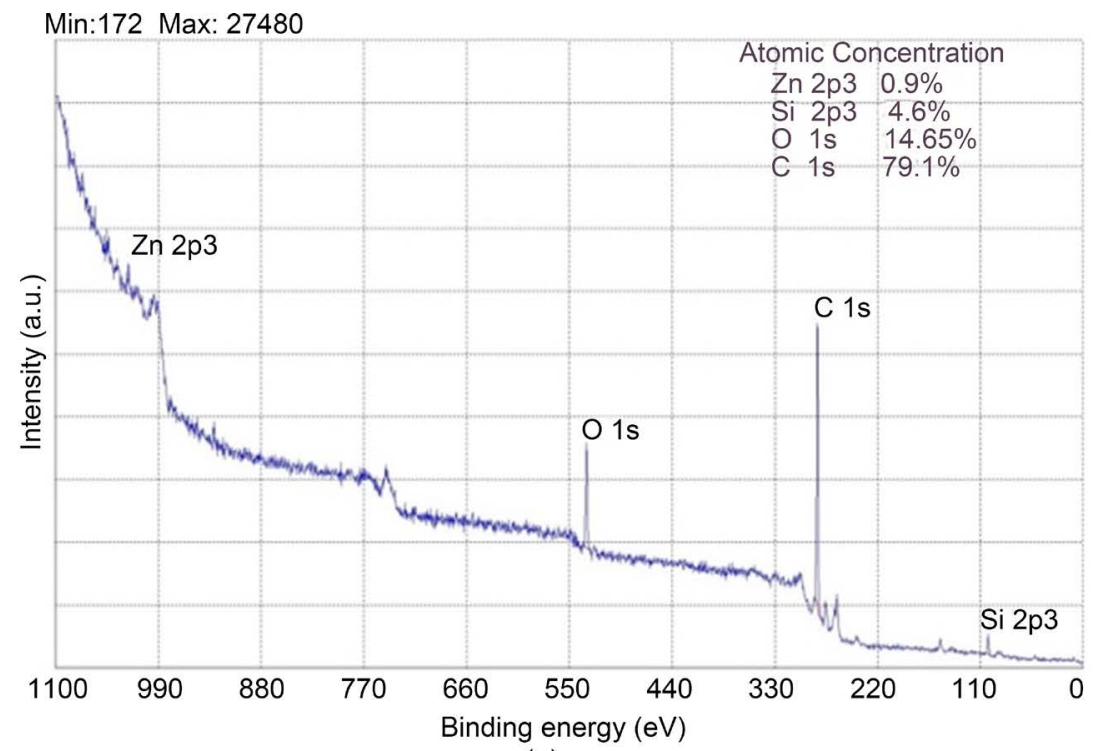

(a)

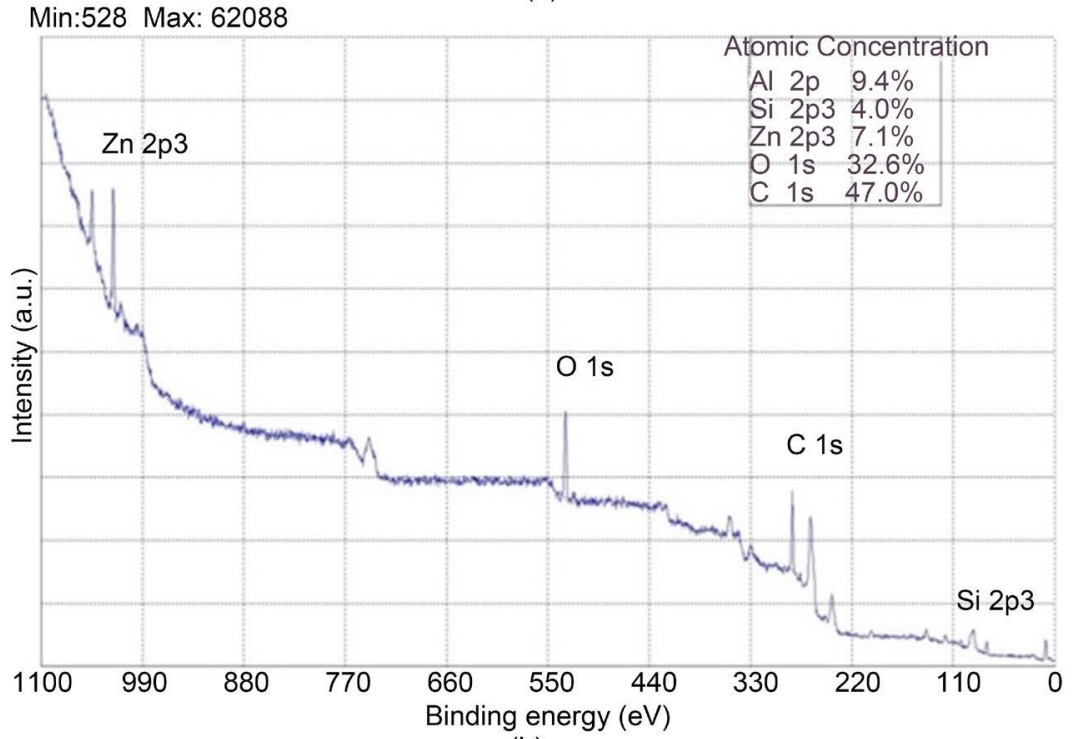

(b)

Figure 4. XPS of $\mathrm{ZnO}$ thin film on $\mathrm{Al}_{2} \mathrm{O}_{3}$ substrate at (a) $T_{s}=400^{\circ} \mathrm{C}$ and $C=0.1$ $\mathrm{mol} / \mathrm{lit}$; and (b) $T s=450^{\circ} \mathrm{C}$ and $C=0.1 \mathrm{~mol} / \mathrm{lit}$.

boundaries with spherical grain shapes [37]. A similar result can be observed in Figure 3(d). Such a transition from an amorphous texture to a larger size of crystallites was also observed in a previous study [38]. The study attributed the observed trend to excess amount of surface-free energy at lower temperature which leads to formation of smooth film surface.

\subsection{Mixed Oxides}

Figure 6 and Figure 7 show the SEM micrographs of $\mathrm{ZnO}+\mathrm{In}_{2} \mathrm{O}_{3}$ and $\mathrm{SnO}_{2}+$ $\mathrm{In}_{2} \mathrm{O}_{3}$ thin films on $\mathrm{Al}_{2} \mathrm{O}_{3}$ substrate. Figure 6(a) and Figure 6(b) are the results for $\mathrm{ZnO}+\mathrm{In}_{2} \mathrm{O}_{3}$ at $T_{s}=400^{\circ} \mathrm{C}$ and concentration ratios of $25 \%$ of $\mathrm{ZnO}$ and $80 \%$ of $\mathrm{ZnO}$ respectively. It has been found that an un-doped $\mathrm{ZnO}$ film will form a non-uniform structure [39]. By doping with indium, the uniformity is enhanced 

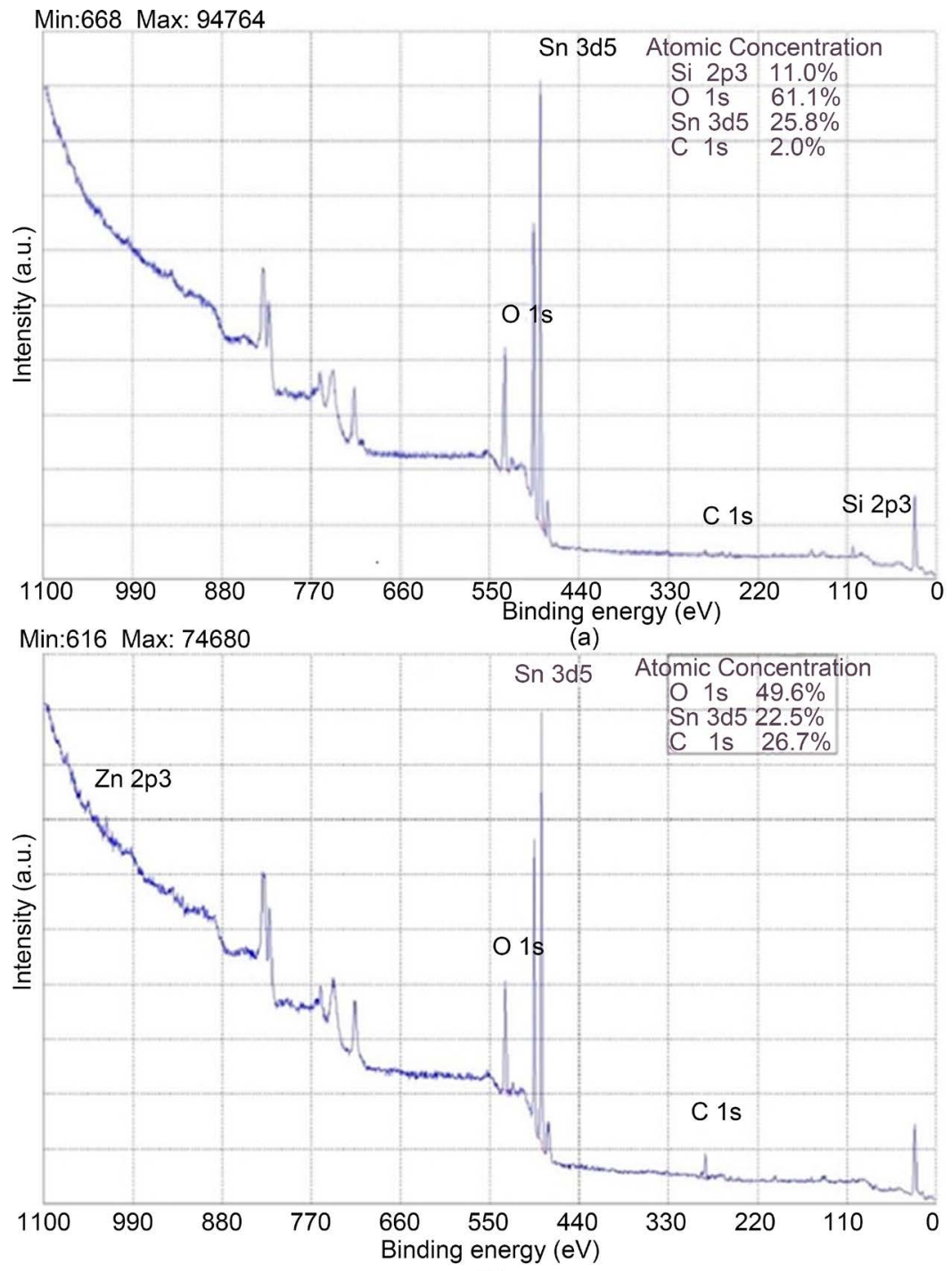

(b)

Figure 5. XPS of $\mathrm{SnO}_{2}$ thin film on $\mathrm{Al}_{2} \mathrm{O}_{3}$ substrate at (a) $T_{s}=450^{\circ} \mathrm{C}$ and $C=0.25$ $\mathrm{mol} / \mathrm{lit}$; and (b) $T_{s}=500^{\circ} \mathrm{C}$ and $C=0.25 \mathrm{~mol} / \mathrm{lit}$.

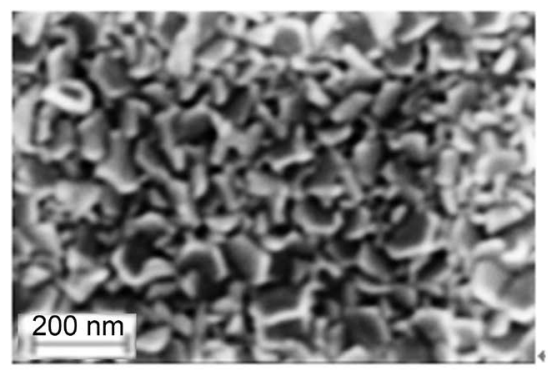

(a) Case 11

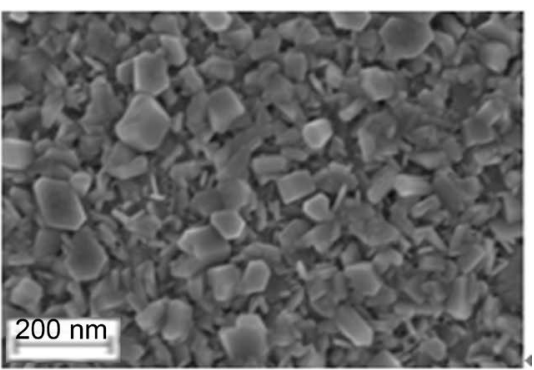

(b) Case 12

Figure 6. SEM micrographs of spray pyrolysis deposition of $\mathrm{ZnO}+\operatorname{In}_{2} \mathrm{O}_{3}$ on $\mathrm{Al}_{2} \mathrm{O}_{3}$ substrate: (a) $0.25 \mathrm{ZnO}+0.75 \mathrm{In}_{2} \mathrm{O}_{3}$ at $T_{s}=400^{\circ} \mathrm{C}$ and $C=0.1 \mathrm{~mol} / \mathrm{lit}$; and (b) $0.8 \mathrm{ZnO}+0.2 \operatorname{In}_{2} \mathrm{O}_{3}$ at $T_{s}=400^{\circ} \mathrm{C}$ and $C=0.1 \mathrm{~mol} / \mathrm{lit}$.

and grain size is increased [39]. At low concentration ratio of $\mathrm{ZnO}$ (Figure 6(a)), $\mathrm{ZnO}$ nano wires are formed. By increasing the amount of $\mathrm{ZnO}$ (from 25\% in Fig- 
ure 6(a) to $80 \%$ in Figure 6(b)), crystallization occurs and a well-structured thin film is produced. These results exhibit the same trend that was observed in a previous Figure 2 for $\mathrm{ZnO}$ films. Thus by increasing the amount of zinc in solution, there is a better chance to produce zinc oxide crystals or rods. In Figure 6 (b), the growth of $\mathrm{ZnO}$ rods occurs fully due to the growth of side walls, resulting in the formation of nano tubes [35] [40] [41]. By increasing the indium dopant, the grain size decreases. This trend is attributed to the stresses applied by the mixture which limits the growth of the grain size [42].

Figure 7 shows the SEM micrographs of $\mathrm{SnO}_{2}+\operatorname{In}_{2} \mathrm{O}_{3}$ thin films deposited on $\mathrm{Al}_{2} \mathrm{O}_{3}$ substrate at $T_{s}=450^{\circ} \mathrm{C}$ and at a concentration ratio of $80 \%$ of $\mathrm{SnO}_{2}$ and $95 \%$ of $\mathrm{SnO}_{2}$ respectively. The results show that small spherical particles are formed at the low concentration of tin (Figure 7(a)). When the concentration of tin is high (Figure $7(b)$ ), the synthesized film is similar to the single oxide thin film of Case 5, resulting in cracking and formation of a thick film.

\subsection{Size Distribution}

Image processing techniques were applied to the SEM micrographs in order to calculate the particle size distribution, specifically the mean diameter of each particle. The average particle size was determined by considering all particle dimensions in the film. The mean area of particles $(\bar{A})$ was calculated by considering the total number of particles and the space intervals thus [43]:

$$
\bar{A}=A+\left(\sum f d / N\right) i
$$

where $\bar{A}$ is actual mean area, $A$ is the assumed mean area, $i$ is the class interval between particles, $d$ is the deviation of midpoint from assumed mean, and $N$ is total number of particles considered. The mean diameter was then obtained from $\bar{A}$ assuming spherical particles.

Table 2 shows the average particle size and standard deviation from average particle size obtained for some of the films produced. The standard deviation values show the dispersion of particle sizes from the measured average particle size for each case. Smaller values of standard deviations indicate narrower range of particle size distribution from average value. It implies simultaneous chemical reactions inside droplets and subsequently a homogenous particle growth on

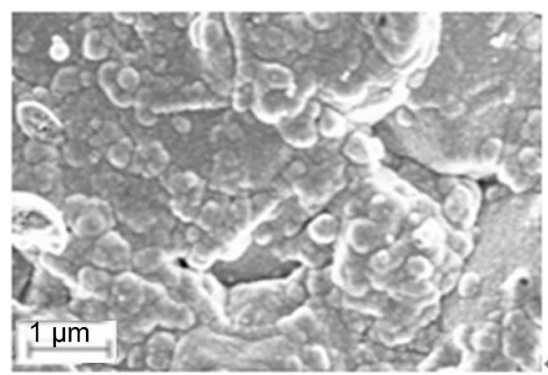

(a) Case 13

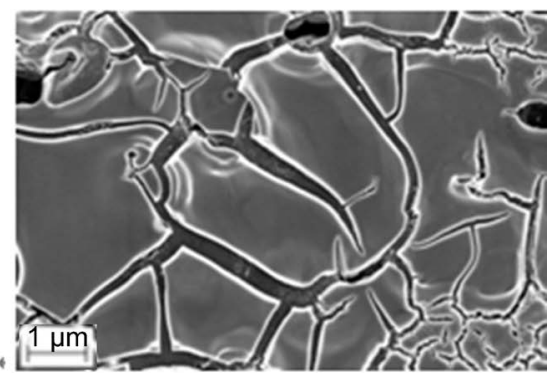

(b) Case 14

Figure 7. SEM micrographs of spray pyrolysis deposition of $\mathrm{SnO}_{2}+\mathrm{In}_{2} \mathrm{O}_{3}$ on $\mathrm{Al}_{2} \mathrm{O}_{3}$ substrate: (a) $0.80 \mathrm{SnO}_{2}+0.20 \mathrm{In}_{2} \mathrm{O}_{3}$ at $T_{s}=450^{\circ} \mathrm{C}$ and $C=0.25 \mathrm{~mol} / \mathrm{lit}$; and (b) $0.95 \mathrm{SnO}_{2}+0.05 \mathrm{In}_{2} \mathrm{O}_{3}$ at $T_{s}=450^{\circ} \mathrm{C} \mathrm{C}$ and $C=0.25 \mathrm{~mol} / \mathrm{lit}$. 
Table 2. Particle size of synthesized $\mathrm{ZnO}$ and $\mathrm{Zno}+\operatorname{In}_{2} \mathrm{O}_{3}$ films.

\begin{tabular}{cccccc}
\hline Case & $\begin{array}{c}\text { Deposited metal } \\
\text { oxide }\end{array}$ & $\begin{array}{c}\text { Temperature } \\
{\left[{ }^{\circ} \mathrm{C}\right]}\end{array}$ & $\begin{array}{c}\text { Concentration } \\
{[\mathrm{mol} / \mathrm{lit}]}\end{array}$ & $\begin{array}{c}\text { Ave. particle } \\
\text { size }[\mathrm{nm}]\end{array}$ & $\begin{array}{c}\text { Standard } \\
\text { deviation } \\
(\sigma)[\mathrm{nm}]\end{array}$ \\
\hline 1 & $\mathrm{ZnO}$ & 400 & 0.1 & 112 & 65 \\
3 & $\mathrm{ZnO}$ & 400 & 0.2 & 119 & 70 \\
4 & $\mathrm{ZnO}$ & 400 & 0.3 & 233 & 89 \\
10 & $\mathrm{SnO}_{2}$ & 450 & 0.5 & 47 & 41 \\
11 & $25 \mathrm{wt} \% \mathrm{ZnO}_{+}$ & 400 & 0.1 & 136 & 94 \\
12 & $\begin{array}{c}75 \mathrm{wt} \% \mathrm{In}_{2} \mathrm{O}_{3} \\
80 \mathrm{wt} \% \mathrm{ZnO}^{2}\end{array}$ & 400 & 0.1 & 201 & 123 \\
13 & $\begin{array}{c}20 \mathrm{wt} \% \mathrm{In}_{2} \mathrm{O}_{3} \\
80 \mathrm{wt} \% \mathrm{SnO}_{2}+\end{array}$ & 450 & 0.25 & 94 & 46 \\
\hline
\end{tabular}

the substrate due to the balance between the substrate temperature and the concentrations of precursors in solution. Figure 8 and Figure 9 show the particle size distributions obtained for $\mathrm{ZnO}$ single oxide and $\mathrm{ZnO}+\mathrm{In}_{2} \mathrm{O}_{3}$ mixed oxide films respectively.

Figure 8 shows that by increasing the concentration of $\mathrm{ZnO}$, the particles grow larger. At low concentration, the particles are smaller and the size distribution is less homogenous (Table 2, Case 1) as was also observed in a previous study [36]. At $C=0.2 \mathrm{~mol} / \mathrm{lit}$ and $T_{s}=400^{\circ} \mathrm{C}$ (Table 2, Case 3), a narrow particle size distribution is observed with high probability of a more homogenous film. Comparing the standard deviation values of cases 1 to 3 shows that more particles within $1 \sigma$ is observed when solution concentration is high and subsequently the homogeneity of particle size is higher. Figure 9 for $\mathrm{ZnO}+\operatorname{In}_{2} \mathrm{O}_{3}$ mixed oxide shows that the addition of indium oxide component to $\mathrm{ZnO}$ results in the growth of particles over a wider range of sizes. Higher standard variation values represents that there is more deviation from average size when a mixed precursor is deposited on the surface. It means that the particles in mixed oxides cases are produced with less homogeneity compared to the single oxides $(\mathrm{ZnO})$ of Figure 8. In the mixed oxide film cases of Figure 9, the results show that a more homogenous particle distribution is obtained when $\mathrm{ZnO}$ is the dominant precursor. The experimental results show that by increasing the amount of $\mathrm{ZnO}$, crystallization occurs and a well-structured thin film is produced. There is therefore a better chance to produce zinc oxide crystals or rods at the higher $\mathrm{ZnO}$ concentration [35]. Thus the overall particle size is reduced when the concentration of indium is increased (Table 1, Case 11). This trend may be attributed to the fact that indium ions limit the growth of $\mathrm{ZnO}$ particles on the surface [39]) which has been also observed in a previous study of the authors [44] or by the increased stresses applied by the mixture which limits the growth of grain size [42].

Figure 10 shows the particle size distribution for $\mathrm{SnO}_{2}$ single oxide and $\mathrm{Zno}+$ $\mathrm{In}_{2} \mathrm{O}_{3}$ mixed oxide films. The single oxide is deposited in the shape of spherical 


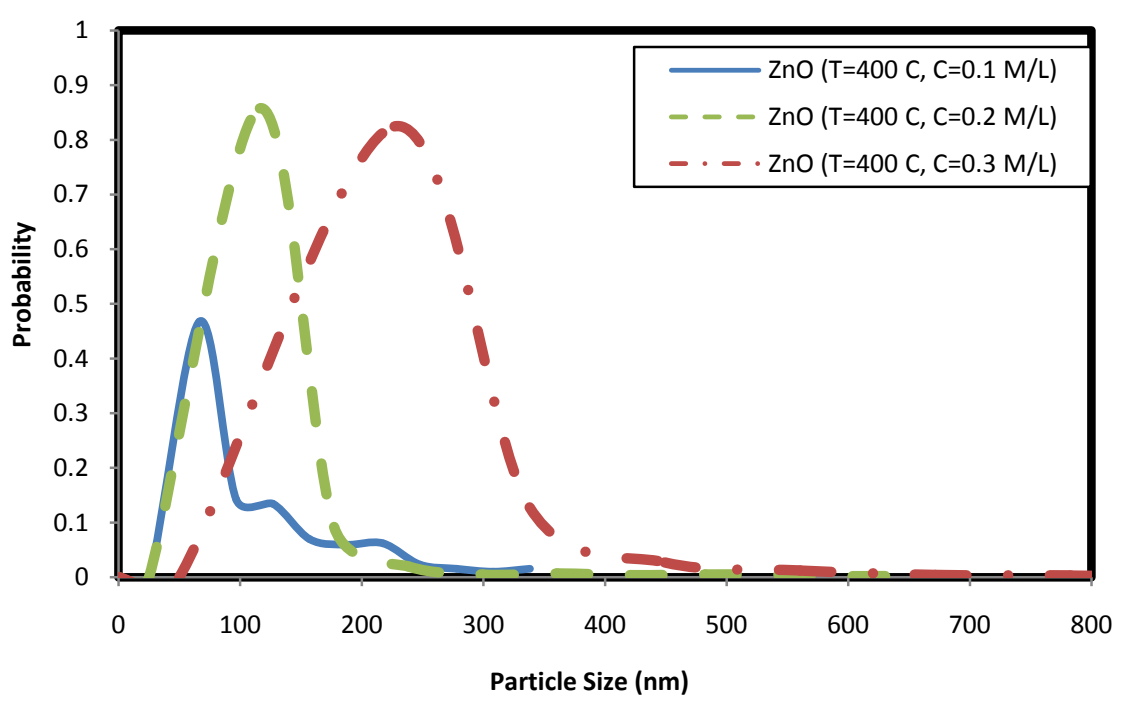

Figure 8. Particle size distribution of $\mathrm{ZnO}$ single oxide thin films.

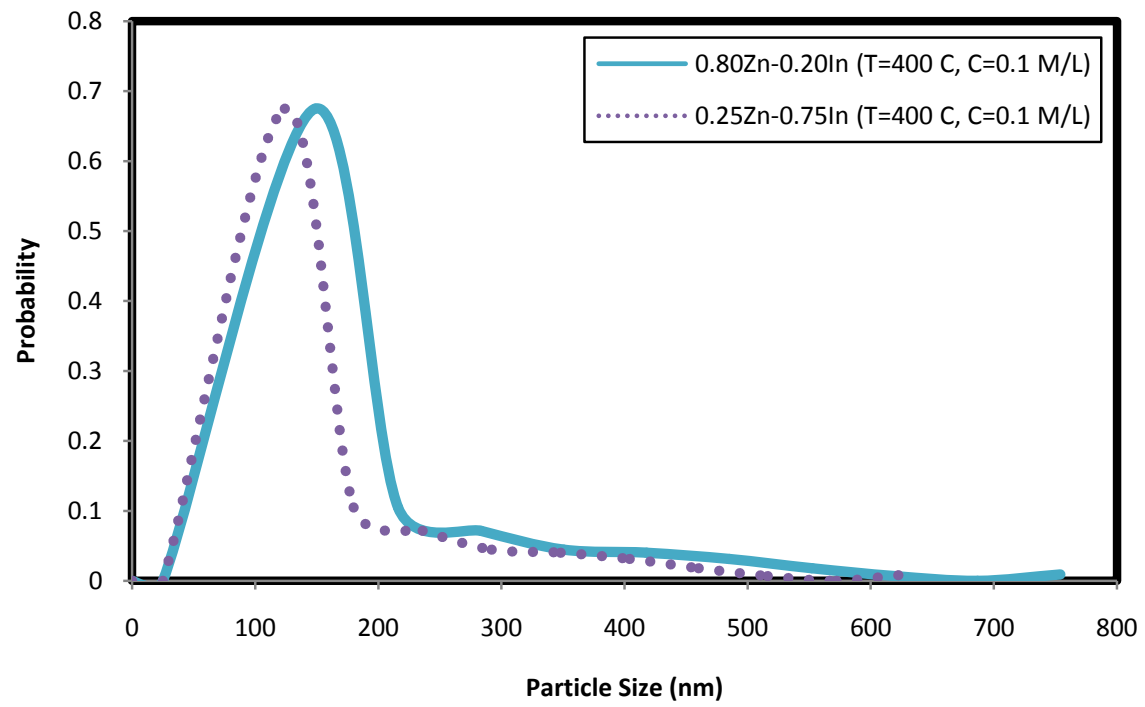

Figure 9. Particle size distribution of ( $\left.\mathrm{x} w \mathrm{wt} \% \mathrm{ZnO}+\mathrm{y} \mathrm{wt} \% \operatorname{In}_{2} \mathrm{O}_{3}\right)$ mixed oxide thin films.

grains with sharp boundaries as indicated in a previous Figure 3(d). The mixed metal oxide is formed with rough structure with larger spherical grains as shown in the previous Figure 7(a). The results show that in the latter case, the particles agglomerate and form larger-sized particles as depicted in Figure 10 (Table 2, Cases 10 and 13).

\section{Discussion}

The processing of single oxide and mixed oxide films by spray pyrolysis technique (SPT) was investigated. Two single oxides $\left(\mathrm{ZnO}\right.$ and $\left.\mathrm{SnO}_{2}\right)$ and two mixed oxides $\left(\mathrm{ZnO}+\mathrm{In}_{2} \mathrm{O}_{3}\right.$ and $\left.\mathrm{SnO}_{2}+\mathrm{In}_{2} \mathrm{O}_{3}\right)$ were considered. The films were processed under varying substrate temperature conditions and different precursor solution concentrations, and deposited on heated $\mathrm{Al}_{2} \mathrm{O}_{3}$ substrates. The films were then characterized by SEM for microstructure and XPS for composition. 


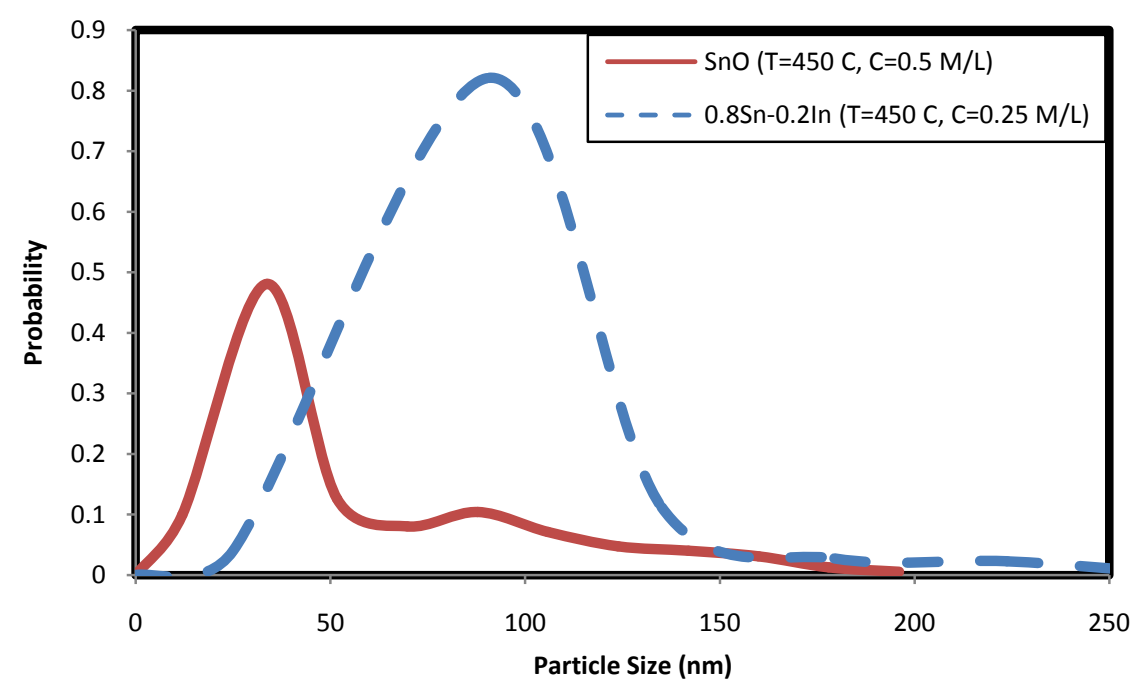

Figure 10. Particle size distribution of $\mathrm{SnO}_{2}$ single oxide and 80 wt. $\% \mathrm{SnO}_{2}+20$ wt. $\%$ $\mathrm{In}_{2} \mathrm{O}_{3}$ mixed oxide thin films.

The findings of the single oxide study can be summarized thus:

- At low temperatures, small spherical crystallites of $\mathrm{ZnO}$ are formed which agglomerate at higher temperature.

- The density and size of $\mathrm{ZnO}$ particles are increased by increasing the solution concentration for deposition at $400^{\circ} \mathrm{C}$. The results show that both low temperature and high concentration will produce packed $\mathrm{ZnO}$ rods.

- $\mathrm{SnO}_{2}$ film with non-homogenous structure is synthesized at $400^{\circ} \mathrm{C}$ which reshapes to porous microstructure by increasing the temperature to $450^{\circ} \mathrm{C}$. The composition of $\mathrm{SnO}_{2}$ is however largely unaffected by temperature above $450^{\circ} \mathrm{C}$.

- It is necessary to increase the concentration of Sn precursor in order to form packed rod arrays.

The study also has demonstrated the similarities and differences between the two metal oxides $\left(\mathrm{ZnO}\right.$ and $\left.\mathrm{SnO}_{2}\right)$, which are considered thus:

a. Non-homogenous film structures are observed at almost the same low temperatures, and crack-free films are formed by increasing the temperature in both cases.

b. $\mathrm{SnO}_{2}$ requires a higher temperature and concentration than $\mathrm{ZnO}$ to produce continuous films.

The findings of the study on the mixed metal oxides $\left(\mathrm{ZnO}+\mathrm{In}_{2} \mathrm{O}_{3}\right.$ and $\mathrm{SnO}_{2}+$ $\mathrm{In}_{2} \mathrm{O}_{3}$ ) can be summarized in the following:

- $\mathrm{ZnO}+\mathrm{In}_{2} \mathrm{O}_{3}$ deposition exhibits increasing particle size with increasing precursor solution concentration and $\mathrm{Zn}$ composition.

- Doping $\mathrm{ZnO}$ with indium oxide component results in a less homogenous particle size distribution. Thus indium ions limit the growth of $\mathrm{ZnO}$ particles in the mixture.

- $\mathrm{ZnO}$ nano wires are grown at low concentration of $\mathrm{Zn}$. By increasing this concentration, $\mathrm{ZnO}$ rods grow and tend to reshape to nano tubes with dis- 
tinct side walls.

- $\mathrm{SnO}_{2}+\mathrm{In}_{2} \mathrm{O}_{3}$ film with more homogenous structure is formed at $80 \%$ ratio of tin. The precursor solution does not have sufficient time to form a continuous film at high concentration of $\mathrm{Sn}$.

These findings could be used to determine processing criteria for each metal oxide film.

\section{Conclusions}

This study has considered the dependence of the morphology of a thin film on the synthesis conditions. The investigation on this dependency has provided a systematic approach for production of a wide range of metal oxide films for next-generation highly selective and sensitive conductometric gas sensors with ultra-fast response. Such sensors are critical to the detection of hazardous environmental substances, and explosives. Specifically, the precise micro-structure of the sensor films determines the adsorption of analyzed gas on the semiconductor particles as well as interaction with the sensitive layer of the film.

The results have shown that this objective could be achieved through careful control of the substrate temperature and concentration of precursor solution. It means that increasing the deposition temperature in a discovered range results in the formation of films with more uniform particle sizes and the size of deposited particles increases with increasing concentration of precursor solution under specified conditions. The deposited particles of the film are not separate crystallites, but splices or aggregates of crystallites. As the results, the conductivity of the sensor film is determined by the electron density in an aggregate and the contacts between aggregates. A comprehensive solution will require investigating other synthesis conditions. The results of further studies could also be useful in the determination of the optimum conditions required to produce the desired films to meet specific performance characteristics.

\section{Acknowledgements}

This project is supported by the National Science Foundation under grant number CMMI-1030689.

\section{References}

[1] Kruis, F.E., Fissan, H. and Peled, A. (1998) Synthesis of Nanoparticles in the Gas Phase for Electronic, Optical and Magnetic Applications-A Review. Journal of Aerosol Science, 29, 511-535. https://doi.org/10.1016/S0021-8502(97)10032-5

[2] Shaginyan, L.R. (1998) Methods of Production, Structure, and Properties of Film Materials Based on the Carbon-Nitrogen System (Survey). Powder Metallurgy and Metal Ceramics, 37, 648-658. https://doi.org/10.1007/BF02680122

[3] Perednis, D. and Gauckler, L.J. (2005) Thin Film Deposition Using Spray Pyrolysis. Journal of Electroceramics, 14, 103-111. https://doi.org/10.1007/s10832-005-0870-x

[4] Kalantar-Zadeh, K. and Fry, B. (2007) Nanotechnology-Enabled Sensors. Springer, New York, 184-186.

[5] Perednis, D. (2003) Thin Film Deposition by Spray Pyrolysis and the Application in 
Solid Oxide Fuel Cells, PhD Dissertation, ETH, Zurich.

[6] George, J. (1992) Preparation of Thin Films. CRC Press, New York, 339-342.

[7] Tofield, B.C. (1987) State of the Art and Future Prospects for Solid State Gas Sensors. In: Moseley, P.T. and Tofield, B.C., Eds., Solid State Gas Sensors, Adam Hilger, Bristol, 198-237.

[8] Vigil, O., Cruz, F., Santana, G., Vaillant, L., Morales-Acevedo, A. and ContrerasPuente, G. (2000) Influence of Post-Thermal Annealing on the Properties of Sprayed Cadmium-Zinc Oxide Thin Films. Applied Surface Science, 161, 27-34. https://doi.org/10.1016/S0169-4332(00)00117-3

[9] Nehru, L.C., Umadevi, M. and Sanjeeviraja, C. (2012) Studies on Structural, Optical and Electrical Properties of $\mathrm{ZnO}$ Thin Films Prepared by the Spray Pyrolysis Method. International Journal of Materials Engineering, 2, 12-17. https://doi.org/10.5923/j.ijme.20120201.03

[10] Dedova, T. (2007) Chemical Spray Pyrolysis Deposition of Zinc Sulfide Thin Films and Zinc Oxide Nanostructured Layers. PhD Dissertation, Tallinn University of Technology, Estonia.

[11] Zahedi, F., Dariani, R.S. and Rozati, S.M. (2013) Effect of Substrate Temperature on the Properties of $\mathrm{ZnO}$ Thin Films Prepared by Spray Pyrolysis. Materials Science in Semiconductor Processing, 16, 245-249. https://doi.org/10.1016/j.mssp.2012.11.005

[12] Korotcenkov, G., Brinzari, V., Schwank, J., DiBattista, M. and Vasiliev, A. (2001) Peculiarities of $\mathrm{SnO}_{2}$ Thin Film Deposition by Spray Pyrolysis for Gas Sensor Application. Sensors and Actuators B: Chemical, 77, 244-252. https://doi.org/10.1016/S0925-4005(01)00741-9

[13] Ikhmayies, S.J. and Ahmad-Bitar, R.N. (2009) Effect of the Substrate Temperature on the Electrical and Structural Properties of Spray-Deposited $\mathrm{SnO}_{2}$ : F Thin Films. Materials Science in Semiconductor Processing, 12, 122-125. https://doi.org/10.1016/j.mssp.2009.09.003

[14] Bai, S., Li, D., Han, D., Luo, R., Chen, A. and Chung, C.L. (2010) Preparation, Characterization of $\mathrm{WO}_{3}-\mathrm{SnO}_{2}$ Nanocomposites and Their Sensing Properties for $\mathrm{NO}_{2}$. Sensors and Actuators B: Chemical, 150, 749-755. https://doi.org/10.1016/j.snb.2010.08.007

[15] Ilican, S., Caglar, Y., Caglar, M. and Yakuphanoglu, F. (2006) Electrical Conductivity, Optical and Structural Properties of Indium-Doped ZnO Nanofiber Thin Film Deposited by Spray Pyrolysis Method. Physica E: Low-dimensional Systems and Nanostructures, 35, 131-138. https://doi.org/10.1016/j.physe.2006.07.009

[16] Rozati, S.M., Zarenejad, F. and Memarian, N. (2011) Study on Physical Properties of Indium-Doped Zinc Oxide Deposited by Spray Pyrolysis Technique. Thin Solid Films, 520, 1259-1262. https://doi.org/10.1016/j.tsf.2011.04.200

[17] Wienke, J. and Booij, A.S. (2013) Spray Deposition of Oxides at Ambient Atmosphere Part 1: Transparent Conductive Oxides.

[18] Bagheri Khatibani, A. and Rozati, S.M. (2013) Synthesis and Characterization of Amorphous Aluminum Oxide Thin Films Prepared by Spray Pyrolysis: Effects of Substrate Temperature. Journal of Non-Crystalline Solids, 363, 121-133. https://doi.org/10.1016/j.jnoncrysol.2012.12.013

[19] Khatami, S.M.N. and Ilegbusi, O.J. (2011) Modeling of Aerosol Spray Characteristics for Synthesis of Mixed-Oxide Nanocomposite Sensor Film. 2011 International Mechanical Engineering Congress and Exposition, Denver, 11-17 November 2011, 581-589. https://doi.org/10.1115/IMECE2011-62252

[20] Khatami, S.M.N. and Ilegbusi, O.J. (2012) Droplet Evaporation and Chemical Reac- 
tion in a Single Multi-Component Droplet to Synthesis Mixed-Oxide Film Using Spray Pyrolysis Method. 2012 International Mechanical Engineering Congress and Exposition, Houston, 9-15 November 2012, 633-638. https://doi.org/10.1115/IMECE2012-86382

[21] Navid Khatami, S.M., Ilegbusi, O.J. and Trakhtenberg, L.I. (2015) Modelling Evaporation and Chemical Reaction in a Multi-Component Droplet from Spray Pyrolysis Synthesis of Mixed Metal-Oxide Nanocomposite Films. International Journal of Mathematical Modelling \& Numerical Optimisation, 6, 141-158.

https://doi.org/10.1504/IJMMNO.2015.069967

[22] Khatami, S.M.N., Kuruppumullage, D.N. and Ilegbusi, O.J. (2013) Characterization of Metal Oxide Sensor Thin Films Deposited by Spray Pyrolysis. 2013 International Mechanical Engineering Congress and Exposition, San Diego, 15-21 November 2013, V010T11A044. https://doi.org/10.1115/imece2013-65136

[23] Khatami, S.M.N., Ilegbusi, O.J. and Trakhtenberg, L. (2013) Modeling of Aerosol Spray Characteristics for Synthesis of Sensor Thin Film from Solution. Applied Mathematical Modelling, 37, 6389-6399. https://doi.org/10.1016/j.apm.2013.01.009

[24] Patil, G.E., Kajale, D.D., Gaikwad, V.B. and Jain, G.H. (2012) Spray Pyrolysis Deposition of Nanostructured Tin Oxide Thin Films. ISRN Nanotechnology, 2012, Article ID: 275872.

[25] Trakhtenberg, L.I.J., Navid Khatami, S.M., Gerasimov, G.N. and Ilegbusi, O.J. (2015) Effect of Composition and Morphology on Sensor Properties of Aerosol Deposited Nanostructured $\mathrm{ZnO}+\mathrm{In}_{2} \mathrm{O}_{3}$ Films. Materials Sciences and Applications, 6, 220-227. https://doi.org/10.4236/msa.2015.63026

[26] Zaier, A., Lakfif, F., Kabir, A., Boudjadar, S. and Aida, M.S. (2009) Effects of the Substrate Temperature and Solution Molarity on the Structural Opto-Electric Properties of ZnO Thin Films Deposited by Spray Pyrolysis. Materials Science in Semiconductor Processing, 12, 207-211. https://doi.org/10.1016/j.mssp.2009.12.002

[27] Bagheri-Mohagheghi, M.M. and Shokooh-Saremi, M. (2004) Electrical, Optical and Structural Properties of Li-Doped $\mathrm{SnO}_{2}$ Transparent Conducting Films Deposited by the Spray Pyrolysis Technique: A Carrier-Type Conversion Study. Semiconductor Science and Technology, 19, 764-769. https://doi.org/10.1088/0268-1242/19/6/019

[28] Hu, J. and Gordon, R.G. (1992) Atmospheric Pressure Chemical Vapor Deposition of Gallium Doped Zinc Oxide Thin Films from Diethyl Zinc, Water, and Triethyl Gallium. Journal of Applied Physics, 72, 5381-5392. https://doi.org/10.1063/1.351977

[29] Hu, J. and Gordon, R.G. (1992) Textured Aluminum Doped Zinc Oxide Thin Films from Atmospheric Pressure Chemical-Vapor Deposition. Journal of Applied Physics, 71, 880-890. https://doi.org/10.1063/1.351309

[30] Zunke, I., Heft, A., Schäfer, P., Haidu, F., Lehmann, D., Grünler, B. and Zahn, D.R.T. (2013) Conductive Zinc Oxide Thin Film Coatings by Combustion Chemical Vapour Deposition at Atmospheric Pressure. Thin Solid Films, 532, 50-55. https://doi.org/10.1016/j.tsf.2012.11.151

[31] Ayouchi, R., Martin, F., Leinen, D. and Ramos-Barrado, J.R. (2003) Growth of Pure $\mathrm{ZnO}$ Thin Films Prepared by Chemical Spray Pyrolysis on Silicon. Journal of Crystal Growth, 247, 497-504. https://doi.org/10.1016/S0022-0248(02)01917-6

[32] Ghimbeu, C.M., Van Landschoot, R.C., Schoonman, J. and Lumbreras, M. (2007) Preparation and Characterization of $\mathrm{SnO}_{2}$ and $\mathrm{Cu}$-Doped $\mathrm{SnO}_{2}$ Thin Films Using Electrostatic Spray Deposition (ESD). Journal of the European Ceramic Society, 27, 207-213. https://doi.org/10.1016/j.jeurceramsoc.2006.05.092 
[33] Chen, Z., Salagaj, T., Jensen, C., Strobl, K., Nakarmi, M. and Shum, K. (2009) ZnO Thin Film Deposition on Sapphire Substrates by Chemical Vapor Deposition. MRS Online Proceeding, 1167, 1167-O07. https://doi.org/10.1557/proc-1167-o07-09

[34] Jiao, B.C., Zhang, X.D., Wei, C.C., Sun, J., Huang, Q. and Zhao, Y. (2011) Effect of Acetic Acid on ZnO: In Transparent Conductive Oxide Prepared by Ultrasonic Spray Pyrolysis. Thin Solid Films, 520, 1323-1329. https://doi.org/10.1016/j.tsf.2011.04.152

[35] Liang, Z., Gao, R., Lan, J.L., Wiranwetchayan, O., Zhang, Q., Li, C. and Cao, G. (2013) Growth of Vertically Aligned ZnO Nanowalls for Inverted Polymer Solar Cells. Solar Energy Materials and Solar Cells, 117, 34-40. https://doi.org/10.1016/j.solmat.2013.05.019

[36] Tucic, A., Marinkovic, Z.V., Mancic, L., Cilense, M. and Miloševic, O. (2003) Pyrosol Preparation and Structural Characterization of $\mathrm{SnO}_{2}$ Thin Films. Journal of Materials Processing Technology, 143, 41-45. https://doi.org/10.1016/S0924-0136(03)00316-9

[37] Patil, P.S., Kawar, R.K., Sadale, S.B. and Chigare, P.S. (2003) Properties of Spray Deposited Tin Oxide Thin Films Derived from Tri-N-Butyltin Acetate. Thin Solid Films, 437, 34-44. https://doi.org/10.1016/S0040-6090(03)00680-1

[38] Smith, A. (2000) Pyrosol Deposition of $\mathrm{ZnO}$ and $\mathrm{SnO}_{2}$ Based Thin Films: The Interplay between Solution Chemistry, Growth Rate and Film Morphology. Thin Solid Films, 376, 47-55. https://doi.org/10.1016/S0040-6090(00)01403-6

[39] Badadhe, S.S. and Mulla, I.S. (2009) $\mathrm{H}_{2} \mathrm{~S}$ Gas Sensitive Indium-Doped ZnO Thin Films: Preparation and Characterization. Sensors and Actuators B: Chemical, 143, 164-170. https://doi.org/10.1016/j.snb.2009.08.056

[40] Miki-Yoshida, M., Paraguay-Delgado, F., Estrada-Lopez, W. and Andrade, E. (2000) Structure and Morphology of High Quality Indium-Doped ZnO Films Obtained by Spray Pyrolysis. Thin Solid Films, 376, 99-109. https://doi.org/10.1016/S0040-6090(00)01408-5

[41] Sivalingam, D., Gopalakrishnan, J.B. and Rayappan, J.B.B. (2012) Nanostructured Mixed $\mathrm{ZnO}$ and $\mathrm{CdO}$ Thin Film for Selective Ethanol Sensing. Materials Letters, 77, 117-120. https://doi.org/10.1016/j.matlet.2012.03.009

[42] Lee, J.H., Lee, S.Y. and Park, B.O. (2006) Fabrication and Characteristics of Transparent Conducting $\operatorname{In}_{2} \mathrm{O}_{3}-\mathrm{ZnO}$ Thin Films by Ultrasonic Spray Pyrolysis. Materials Science and Engineering B, 127, 267-271. https://doi.org/10.1016/j.mseb.2005.10.008

[43] Gupta, S.P. (1985) Measures of Dispersion, Statistical Methods. Sultan Chand and Sons, New Delhi.

[44] Navid Khatami, S.M., Ilegbusi, O.J. and Trakhtenberg, L.I. (2015) Mathematical Modeling and Experimental Validation of Mixed Metal Oxide Thin Film Deposition by Spray Pyrolysis. Materials Sciences and Applications, 6, 68-77. https://doi.org/10.4236/msa.2015.61009 
Submit or recommend next manuscript to SCIRP and we will provide best service for you:

Accepting pre-submission inquiries through Email, Facebook, LinkedIn, Twitter, etc. A wide selection of journals (inclusive of 9 subjects, more than 200 journals)

Providing 24-hour high-quality service

User-friendly online submission system

Fair and swift peer-review system

Efficient typesetting and proofreading procedure

Display of the result of downloads and visits, as well as the number of cited articles Maximum dissemination of your research work

Submit your manuscript at: http://papersubmission.scirp.org/

Or contact msa@scirp.org 